\title{
Skin of the Trunk
}

National Cancer Institute

\section{Source}

National Cancer Institute. Skin of the Trunk. NCI Thesaurus. Code C12295.

The skin or integument surrounding the trunk of the body. 